\title{
Arbitration Award of ICSID on the Investment Disputes of Churchill Mining PLC v. Republic of Indonesia
}

\author{
Yordan Gunawan \\ Faculty of Law, Universitas Muhammadiyah Yogyakarta \\ Jln. Ring Road Barat, Tamantirto, Bantul, Yogyakarta 55183, Indonesia \\ Tel./Fax:+62-274-387656E-mail: yordangunawan@umy.ac.id
}

Submitted: Feb 25, 2017; Reviewed: Mar 22, 2017; Accepted: Mar 28, 2017

\begin{abstract}
The research is aimed at analyzing the ICSID (International Centre Settlement Investment Dispute) decision in solving a dispute between Churchill Mining PLC and the Government of the Republic of Indonesia. The case brought to the public attention, because mining license owned by PT. Ridlatama which acquired from Churchill Mining PLC had been revocated. Churchill Mining PLC holds 75\% share of PT. Ridlatama and it suffered losses caused by the revocation of its mining license. Churchill Mining PLC filed the case to the local court but it failed. Churchill Mining PLC then sought ruling from International arbitration or ICSID. On December 6, 2016, ICSID issued a decision that clearly threw out Churchill Mining PLC claim. ICSID, the World Bank court, ordered the firm to pay a total of US\$.9.446.528 in cost to the Government of the Republic of Indonesia. It is based on the evidences that the UK-Australia company did the fraud and had document forgery of coal mining permit in East Kutai, Indonesia. So the firm has violated the Bilateral Investment Treaties between Indonesia-UK and Indonesia-Australia.
\end{abstract}

Keywords: Bilateral Investment Treaty; ICSID; International Arbitration

DOI: 10.20956/halrev.v3i1.948

\section{INTRODUCTION}

Indonesia is a rich country with abundant of natural resources and energy. Those resources can be found in all over 437 mining sites in West and East Indonesia such as copper and gold in Papua, gold in Nusa Tenggara, nickel in Sulawesi and East Island, bauxite and coal in Borneo, and other minerals in many other places. ${ }^{1}$

\footnotetext{
Gatot Supramono. (2012). Hukum Pertambangan Mineral dan Batu Bara di Indonesia, Jakarta: Rineka Cipta, p.1.
}

Those resources are fully under control of the state. It includes the authority to regulate, manage and supervise the management or the enterprise of mineral, and obligation to utilize maximally for the prosperity of people. $^{2}$ Regarding the mining, in Article 4 section 1 of Law No. 4 of 2009 on Mineral and Coal Mining state that: "Minerals and coal as a non-renewable natural resource constitutes national wealth that is to be con-

\footnotetext{
Salim H.S. (2005). Hukum Pertambangan di Indonesia, Jakarta: Rajawali Pers, p.6.
} 
trolled by the State for the greater prosperity of the Indonesian people. ${ }^{3,}$

The activity of empowerment and utilization of natural resources were called as mining activity. The mining activity cannot be separated from investment, either from domestic or foreign investors. Investment on mining need to be protected because the investor' rights, assets, and capital raised income for the government through royalty and tax. Though investment brought income to the government and local authority, it sometimes created problems and disputes.

Indonesia won a US\$2 billion dispute after the International Centre for Settlement of Investment Disputes (ICSID) tribunal threw away the claim of Churchill Mining Plc. It was ordered to pay a total of US\$9.446.528 to the Indonesian government. The winning against the Churchill Mining PLC's claim is a good achievement by Indonesia because it is the first time Indonesia won the international arbitration case. The former East Kutai Regent Isran Noor, said this is good news for Indonesia. "We won an arbitration dispute in an international tribunal. This is the evidence of our sovereignty over the management of Indonesia's natural resources. ${ }^{4}$ "

On December 6, 2016, ICSID Tribunal Assembly issued the award for case No. $\mathrm{ARB} / 12 / 14$ and 12/4. The researchers would like to analyze the decision of ICSID Tribunal whether the procedure in ICSID had complied with the ICSID Convention. From the explanation above, the author would like

Law No. 4 of 2009 on Mineral and Coal Mining article 4 section 1

4 Tempo.co. "Indonesia Wins International Tribunal against Churchill Mining”. Available from https://goo. $\mathrm{gl} / \mathrm{sOKZzO}$ [Accessed on December 22, 2017] to know whether the procedures of decision making regarding the case between Churrchill Mining PLC and Republic of Indonesia comply with ICSID Convention or not.

\section{ANALYSIS DAN DISCUSSION \\ The Aims of the Establishment of ICSID}

The International Centre for Settlement of Investment Disputes (ICSID or the Centre) was established by the Convention on the Settlement of Investment Disputes between States and Nationals of Other States (the ICSID Convention or the Convention) $)^{5}$. This is an international arbitration institution which established in 1965 for legal dispute resolution and reconciliation between international investors. This law institution is part of and funded by the World Bank Group, headquartered in Washington DC.

The ICSID Convention is a multilateral treaty formulated by the Executive Directors of the World $\mathrm{Bank}^{6}$ to further the Bank's objective of promoting international investment. ICSID is an independent, depoliticized and effective dispute-settlement institution. Its availability to investors and States helps to promote international investment by providing confidence in the dispute resolution process. It is also available for state-state disputes under investment treaties and free trade agreements, and as an administrative registry.

The ICSID Convention also provides the arbitral tribunal with great discretion regarding cost allocation. The ICSID Convention merely states that the tribunal shall

Convention on the Settlement of Investment Disputes between States and Nationals of Other State, 2016.

6 Mohammad Naqib Ishan Jan. (2012). International Dispute Settlement Mechanism, Kuala Lumpur: IIUMPress, p. 188 
decide how and by whom the costs of the arbitration shall be paid. There is no specific guidance in the ICSID Convention as to any principles that the arbitral tribunal should use to allocate costs between the parties (e.g., equal sharing of costs). ${ }^{7}$

ICSID provides for settlement of disputes by conciliation, arbitration or factfinding. The ICSID process is designed to take account of the special characteristics of international investment disputes and the parties involved, maintaining a careful balance between the interests of investors and host States ${ }^{8}$. Each case is considered by an independent Conciliation Commission or Arbitral Tribunal, after hearing evidence and legal arguments from the parties. A dedicated ICSID case team is assigned to each case and provided expert assistance throughout the process. More than 600 such cases have been administered by ICSID till today.

ICSID also promotes greater awareness of international law on foreign investment and the ICSID process. It has an extensive program of publications, including the leading ICSID Review-Foreign Investment Law Journal and it regularly publishes information about its activities and cases. ICSID staffs organize events, give numerous presentations and participate in conferences on international investment dispute settlement worldwide.

\section{Arbitration}

Arbitration was first used by the ancient

Kabir Duggal \& Gerrit Niehoff. (2017). "The Conflicting Landscape Relating to Costs in InvestorState Arbitration", Indian Journal of Arbitration Law, 5(2): 164-176

$8 \quad$ See Rasyid Syed Khalid and Syed Ahmad Idid. (2009). Mediation and Arbitration in Asia Pacific, Malaysia: IIUMPress, p.98
Greek city States to settle their dispute ${ }^{9}$. Arbitration is a process which two or more parties submit their dispute to one or more people impartially which is commonly called as abitrators in order to obtain a decision which is final and binding. There are three things that must be met in a process of arbitration, those are: the existence of a dispute, deal to hand over to a third party, and the final and binding decision that will be dropped. According to Mertokusumo, arbitration is a dispute settlement procedure out of court by consent of the parties to submit their dispute to an arbitrator or arbiter. ${ }^{10}$

Definition of Arbitration, according to article 1 section 1 of the Law No. 30 of 1999 on Arbitration and Alternative Dispute Resolution, Arbitration is a way of settlement of civil disputes outside the courts of general jurisdiction based on the arbitration agreement made in writing by the parties dispute. ${ }^{11}$

Henry Campbell defined arbitration as the reference of a dispute to an impartial (third) person chosen by the parties to the dispute who agree in advance to abide by the arbitrator's award issued after a hearing at which both parties have an opportunity to heard. Jean Robert defined arbitration means instituting a private jurisdiction by which litigations are withdrawn from the public jurisdictions in order to be resolved by individual vested, for a given case, with the powers to judge such litigation. ${ }^{12}$

\footnotetext{
Kaczarowska Alina. (2010). Public International Law. London and New York: Routledge, p. 626

10 Sudikno Mertokusumo. (1999). Mengenal Hukum: Suatu Pengantar, Yogyakarta: Liberty, p.144.

11 Law No. 30 of 1999 on Arbitration and Alternative Dispute Resolutions, article 1 section 1.

12 Huala Adolf. (2002). Arbitrase Komersial Internasional, Jakarta: PT. Rajagrafindo Persada. p.10
} 


\section{Ad-hoc arbitration}

Ad-hoc arbitration that so-called "voluntary arbitration" or "individuals' arbitration" is arbitration which is set up specifically to resolve or decide certain disputes. The status and whereabouts is only to serve and to decide certain disputes. Once the dispute is completed, the existence and function of ad hoc arbitration automatically disappeared and an ended. Basically, the types of ad hoc arbitration is not attached and associated with one of the arbitration body. Therefore, this type of arbitration does not have its own rules of procedure either on the appointment of the arbitrators and the procedure of the dispute. The appointment of arbitrators in ad hoc arbitration can be determined and selected based on agreement between the parties.

\section{Institutional arbitration}

Institutional arbitration is an arbitration body which is permanent. Therefore, institutional arbitration is also called as "permanent arbitral body". Arbitration is provided by a particular organization and intentionally built to accommodate disputes arising from the agreement. Deliberate factors and permanent nature are characteristic that distinguishes institutional arbitration from ad hoc arbitration ${ }^{13}$

Some common institutions are the London Court of International Arbitration (LCIA), the International Chamber of Commerce (ICC), the Dubai International Finance Centre (DIFC) and the Dubai International Arbitration Centre (DIAC) ${ }^{14}$.

13 M. Yahya Harahap. (2003). Arbitrase, 2nd Edition, Jakarta: Sinar Grafika, p.104

14 See Blackaby Nigel, Constantine Partasides, Alan Redfern, Martin Hunter. (2015). Redfern and Hunter
There are approximately 1200 institutions worldwide which offer arbitration services, and some will deal with a particular trade or industry. Care should be taken in the selection process as some institutions may act under rules which are not adequately drafted.

\section{Case of Churchill Mining PLC v. Republic of Indonesia \\ Introduction of the case}

Churchill Mining PLC is a mining corporation from London, United Kingdom. Its main activity is coal mining. ${ }^{15}$ Churchill Mining PLC ("Churchill" or "the Company") was listed on the Alternative Investment Market (AIM) of the London Stock Exchange in April 2005. It also is active in Australia. David F Quinlivan is the executive chairman of Churchill Mining ${ }^{16}$ Churchill's growth path accelerated following the discovery of a world-class thermal coal deposit in the East Kutai Regency of Kalimantan ("EKCP"), Indonesia following an intensive and targeted exploration program.

Churchill had taken the EKCP discovery through the feasibility in readiness for funding and the commencement of construction. Churchill Mining has a significant thermal coal development project located in the East Kutai Regency of Kalimantan, Indonesia. The company wanted to be active in coal mining in Kutai National Park, which is a major menace to orangutans. Since Churchill and its partners were subjected

on International Arbitration, 6th Edition, New York: Oxford University Press, p. 149

15 Source: Wikipedia. https://en.wikipedia.org/wiki/ Churchill Mining [Accessed on January 2, 2017]

16 Churchill Mining Plc. Profile. Source: http://www. churchillmining.com/corporate/directors/ [Accessed on January 2, 2017] 
to a negative ruling from the regional Samarinda Administrative Tribunal that sought to ratify the Regent improper unilateral decision to revoke the EKCP licenses. Churchill appealed the decision to the Administrative High Court in Jakarta which dismissed the appeal and then filed the case to the Indonesian Supreme Court. The Supreme Court of Indonesia rejected an appeal to get compensation for a coal project that the company says was unfairly seized.

Then, Churchill Mining submit lawsuit to the ICSID on 22 June 2012 based on bilateral investment treaties (BIT) between Indonesia-UK and Indonesia-Australia. Churchill sue 8 persons among others were Isran Noor ${ }^{17}$, Susilo Bambang Yudhoyono (former President of Indonesia), Minister of Foreign Affairs of 2012 (Marty Natalegawa), Minister of Energy and Mineral Resources of 2012 (Jero Wacik), Coordinator of Capital Investment Agency of 2012 Muhammad Chatib Basri. ${ }^{18}$

The issue is risen when the regent of East Kutai revoke the license of mining of the PT Ridltama. Unfortunately, Churchill has acquired $75 \%$ of share of the PT.Ridltama which makes the acquisition of the PT Ridltama. Then Churchill firm experienced losses because of the revocation of mining license.

17 Tempo.co. "Indonesia Menang atas Gugatan Arbitrase Churchill Mining". https://m.tempo.co/read/ news/2016/12/08/058826336/indonesia-menang-atasgugatan-arbitrase-churchill-mining [Accessed on January 02, 2017]

18 Hukum Online. "Pemerintah Digugat Perusahaan Tambang Asing”. http://www.hukumonline.com/ berita/baca/lt4fdb7aa9c6744/pemerintah-digugatperusahaan-tambang-asing [Accessed on January 02, 2017]

\section{Chronology of the case}

In line with the procedure of ICSID, Churchill is possible to propose cancellation of decision through application letter to the Secretary General with the reason that the trial is not held properly. Churchill and Planet company registered the suit to ICSID on 22 June 2012 and 26 December 2012 based on bilateral investment treaties (BIT) Indonesia-England and IndonesiaAustralia both of them, suit the Indonesian government on the basis of series of action that led to indirect expropriation and unfair and inequitable treatment, which cause losses to their investments in Indonesia through revocation of Mining Authority/ Mining Business License of Exploitation of plaintiff's business partners by East Kutai Regent on May 24, 2010.

The plaintiffs claim damages in amount of USD 1,14 billion and added by interest of USD 16 million so the total amount is USD 1,31 billion. ICSID Tribunal Assembly in this case is consisting of Professor Gabrielle Kaufmann-Kohler as President Tribunal, Mr. Michael Hwang S.C. and Professor Albert Jan van den Berg as arbitrator.

On February 24, 2014, ICSID Tribunal Assembly issued the decision that ICSID is authorized to investigate and adjudicate the arbitration suit; other things such as document forgery indication by the plaintiffs would be the agenda in the trial of main case investigation trial. Although the ICSID Tribunal Assembly had issued the jurisdiction decision, the Indonesian government still sought that the matter of allegation of document falsification must be completed firstly and separated from the examination 
of principal case. Thus, on September 24, 2014, Indonesian governments propose application to the ICSID Tribunal Assembly to stop all the arbitration process that based on the fake mining license or forged. Indonesian government also ask ICSID Tribunal Assembly to investigate the allegation of the document forgery firstly before entering into the main case

In line with the view of plaintiff, initially the ICSID Tribunal Assembly refused the dismissal request of Indonesian government but because of the persistent effort and no surrender spirit, the Indonesian government requested the ICSID Tribunal Assembly to reconsider their refusal by expressing the views and argument of importance of the matter of settlement of document falsification first and separate from the examination of main case. In November 2014, the ICSID Tribunal Assembly accepted the Indonesian view and decided to examine the issue of documents forgery first before going to the principal case.

In August 2015, the Assembly of the ICSID Tribunal held seven (7) days of hearings of documents validity (hearing on document authenticity) held in Singapore. Before and during the trial, Indonesian government had provided strong evidences and arguments in order to demonstrate and convinced the ICSID Tribunal Assembly that the mining permit that become the basis of Plaintiffs claim as well as several other related documents are really false or forged.

After the trial, ICSID Tribunal Assembly asked the parties to submit a final view of each party (post hearing briefs) including comments on a case (Minnotte v Poland) which also a reference for ICSID Tribunal Assembly to draft the decision. On the delivery of the documents, Indonesian government consistently made effort to make sure the ICSID Tribunal Assembly that the whole of the arbitration claim of the claimants has to be cancelled as the legal consequence of the documents falsification that becomes the basis of the claim of the claimant.

The ICSID Tribunal Assembly in December 6, 2016 issued award that clearly rejects all the claim that delivered by claimant. Some of the important points that became the basis consideration of ICSID Tribunal Assembly are as follow:

a. The arbitration claim was based on 34 documents from the three level of Indonesian Government (Regency, Province and Central) that certainly false/ falsified. Those documents were used by the claimant through the business partner (Ridltama Group) to get the mining license in the East Kutai Regency, Province of East Kalimantan;

b. Those false documents imply pollute the investment claim of claimant. So, investment of claimant is not protected by the bilateral investment treaty between Indonesia-UK and IndonesiaAustralia because of the falsification the claimant has violated the good faith principle and international public policy.

c. Considering that all the investment of claimant was illegal because of many falsifications, the ICSID Tribunal Assembly decided that all the claims of claimant cannot be accepted including any other effort that done by claimant 
as long as this arbitration process was running.

d. ICSID Tribunal Assembly also stated that the claimant is not proportionally conduct due diligence in Indonesian investment

Through this decision, ICSID Tribunal Assembly ordered all claimants to pay the cost of the case that has been spent by Indonesian Government for USD 9,464,528 ( $75 \%$ of total that has been spent by Indonesian Government). The claimants were also burdened to replace all cost that had been spent by Indonesian Government for ICSID administration for USD 800,000. The ICSID Tribunal Assembly awards also strengthen the truth of East Kutai Government action of revoking the mining license of business partner of claimant as what strengthen by the Decision of Administrative Court. In this arbitration process Indonesian Government was represented by Minister of Law and Human Right as coordinator receiver Special Full Power of President of Indonesia. This win is very good results of the persistent and tireless effort of Indonesian Government for around 5 years since the case was began

This win was also important and regarded as historic achievement. The result achieved by this arbitration would become the strength signal for investor, without having good faith, should not do cheating or violating the law in Indonesia. This award also gives positive signal on the seriousness of Indonesian government in protecting other good investors to continually keep the healthy investment in Indonesia. ${ }^{19}$

19 Pojok Satu. "Indonesia Menang Melawan Churchill". Available online at: https://goo.gl/r9aiua [Accessed on Dec 21, 2016]

\section{Analysis of the Case and Analysis of ICSID Award}

Essentially, the case of Churchill Mining PLC and Planet Mining Pty Ltd v. Republic of Indonesia submission to ICSID issue is under the agreement between the Government of the United Kingdom of Great Britain and Northern Ireland and the Government of Republic of Indonesia for the Promotion and Protection of Investments (the "UKIndonesia BIT", the "Treaty", or the "BIT") $)^{20}$ dated April 27, 1976 and enter into force on 24 March 1977.

This began on May 22, 2012, in which Churchill filed a request for arbitration to ICSID which pursuant to Article 36 of the ICSID Convention and the UK-Indonesia BIT, which leads in the case of a mining block, opened by Churchill in East Kutai, Kalimantan, Indonesia. All the preliminary procedures initiated in accordance premises what is listed on the ICSID Convention in Arbitration Chapter. The Secretary-General of the Centre registered Planet's Request for Arbitration pursuant to Article 36 (3) of the ICSID Convention under ICSID No. ARB/12/40. ${ }^{21}$ On 22 January 2013, pursuant to the Parties' agreement, an Arbitral Tribunal also comprised of Prof. Gabrielle Kaufmann-Kohler (President), Prof. Albert Jan van den Berg, and Mr. Michael Hwang S.C. It was constituted in accordance with Article 37(2) (a) of the ICSID Convention, and the proceedings commenced on that date, on June 22, 2012.

\footnotetext{
20 The Award of ICSID on Churchill Mining PLC and Planet Mining Pty Ltd v. Republic of Indonesia

21 The Award of ICSID on Churchill Mining PLC and Planet Mining Pty Ltd v. Republic of Indonesia
} 
After setting a schedule between the parties, the Tribunal held a hearing on jurisdiction in Singapore on May 13-14, 2013. The next process which dated on February 24, 2014, the Tribunal issued the Decisions on Jurisdiction, which respect of Churchill and Indonesia, the Tribunal decided that it had jurisdiction over the dispute submitted to it in this arbitration and reserved its decision on costs.

Before entering the next stage, Republic of Indonesia believes that there is against counterfeiting files on 34 business licensing procedures in foreign investment in Indonesia. Therefore, the republic of Indonesia as a respondent, were initiated for Inspection of Claimants' Original Documents, along with a List of Disputed Documents and Mr. Gideon Epstein's Forensic Handwriting Examination Report dated May 9, 2014. And it was on May 16, 2014. And this lasted until the response of the Claimants if the Tribunal were inclined to order the inspection of any of the original documents identified by the Respondent, the Tribunal should also order the Respondent to produce for inspection the originals identified by the Claimants in its response. However, the inspection of the documents was took place in Singapore ${ }^{22}$ on Augustus 25, 2014.

ICSID Convention Relevant to the Investment Dispute: According to General Procedural Provisions

Arbitration is a private, informal process by which the parties to a contract agree, in writing, to submit their disputes to one or

22 The Award of ICSID on Churchill Mining PLC and Planet Mining Pty Ltd v. Republic of Indonesia more impartial persons who will adjudicate and resolve the controversy by rendering a final and binding award. It is used for a wide variety of disputes - from commercial disagreements involving technology, intellectual property, major commercial activities, construction, securities transactions, realestate, insurance claims and employment grievances. $^{23}$

After more than 3 times the legal action in Indonesia with zero results, finally, Churchill decided to sue Indonesia to ICSID in which both parties agreed on and passed in accordance with its systematic procedures. As mentioned in the Convention "Any Contracting State or any national of a Contracting State wishing to institute arbitration proceedings shall address a request to that effect in writing to the Secretary-General who shall send a copy of the request to the other party." ${ }^{2425}$ It is also in accordance with "The Arbitral Tribunal (hereinafter called the Tribunal) shall be constituted as soon as possible after registration of a request pursuant to Article $36 .{ }^{\circ 2627}$

In this case, it clearly involves two parties with different country, however the essential characteristics of arbitration are its private nature, voluntary and confidential, which at first glance may give the impression of an institution less "endowed" with strict

23 Aiste Sklenyte, (2003). International Arbitration: The Doctrine of Separability and Competence-Competence Principle. Aarhus: Winter, p. 6.

24 ICSID Convention 2016, Article 36

25 Mateus Aimoré Carreteiro. (2016), "Appellate Arbitral Rules in International Commercial Arbitration". Journal of International Arbitration, 33(2): 185-216.

26 ICSID Convention 2016, Article 37

27 Turner Ray. (2005). Arbitration Award: A Practical Approach. Australia: Blackwell Publishing, p.33 
rules of substantive and procedural law. ${ }^{28}$ Parties are free to choose or even to develop rules that may constitute into an arbitration proceeding, compulsory for the parties and arbitrators, respected and applied by them.

\section{The Complaint of Churchill}

Churchill believes that with the revocation of a mining permit made by the regent of East Kutai, it equals to terminate the entire mining activities that have long runs. In addition to the disputes relating to foreign investment, it also involves the case of falsifying of signatures on important documents that were required as a condition of foreign investment and business license in Indonesia. It should be underlined that in this case, the signatures forgery was the main focus. Both parties have different perspectives related to this. It is clearly stated by Churchill as the Claimants, the most important issue is not "how" the signatures were affixed on the disputed documents, nor "who" did so, but whether the signatures were authorized. Moreover, According to the Claimants, Indonesia failed to provide "clear and convincing evidence" that the disputed documents were forged and fabricated by Ridlatama, let alone to prove the existence of a "massive, systematic and sophisticated scheme to defraud" the Respondent. ${ }^{29}$

In the course of this arbitration, both parties are equally adamant that they both have a corroboration of their respective parties, in a way, both parties blades often make letters and rejoinder to a rebuttal of

28 Diana Loredana Hogaş. (2014). "Principles of law applicable to the arbitration proceedings". Juridical Tribune 4(2): 128-145.

29 The Award of ICSID on Investment Dispute between Churchill Mining PLC and Republic of Indonesia. each party. For Indonesia, the signatures in documents no. 1-32 in the Document Table were produced "by a piece of very sophisticated technology, most probably an autopen device". ${ }^{30}$ Indonesia's expert, Mr. Epstein, confirmed in his reports and at the hearing that Messrs. Ishak, Noor and Setiawan did not sign the disputed documents and that their signatures had been affixed with a so-called "autopen". ${ }^{31}$ An autopen uses a master signature that is programed through a smart card or flash drive so as to produce identical signatures in ink. ${ }^{32}$

The cases keep rolling until came into the pre-hearing phase, post-hearing phase and the Award of the Arbitration. In this dispute, all costs are borne by both parties, but after going through a long process of arbitration, and clearly proven that the Churchill clearly guilty of falsifying documents in the business license, Indonesia as the respondent received compensation from Churchill with the amount of IDR 114,3 billion.

In fact, to Indonesia the Claimants bear the initial burden of proving the existence of an investment, including demonstrating the authenticity of the mining licenses. ${ }^{33}$ Thus, the Claimants must "establish that the foundational evidence supporting their claims [...] inspires at least a 'minimally

30 R-PHB1, paragraph 4 on The Award of ICSID on Churchill Mining PLC and Planet Mining Pty Ltd v. Republic of Indonesia.

31 Application for Dismissal, paragraph 23; Tr. (Day 1), 28:20 (Opening, O’Donoghue); Epstein ER1, pp. 6-7; Epstein ER2, p. 8 on The Award of ICSID on Churchill Mining PLC and Planet Mining Pty Ltd v. Republic of Indonesia.

32 Application for Dismissal, note 27; Epstein ER2, p. 8 on The Award of ICSID on Churchill Mining PLC and Planet Mining Pty Ltd v. Republic of Indonesia.

33 R-Answers, paragraph 176; Tr. (Day 1), 25:8-12 (Opening, Frutos-Peterson) on The Award of ICSID on Churchill Mining PLC and Planet Mining Pty Ltd v. Republic of Indonesia. 
sufficient degree of confidence in its authenticity". ${ }^{34}$

In this arbitration process, all the evidence clearly showed that Churchill had been falsifying documents on a mining license in East Kutai, with a strong statement of the results of research that the use of $\mathrm{Mr}$. Ishak's signature was not authorized. The evidence establishes that Mr. Ishak did not authorize the placement of his signature on the disputed documents (consist of 18 Documents) When Mr. Ishak was away, Mr. Noor would sign for him, but in his capacity as Deputy Regent, not with Mr. Ishak's name. ${ }^{35}$ According to Indonesia, the following elements corroborate this conclusion:

a. Numerous irregularities in the Licenses;

b. Application process;

c. Maps attached to the Mining Licenses;

d. Unregistered Documents; and

e. No handover ceremonies.

The steps taken by the ICSID to grant the request of the Republic of Indonesia which wanted the authentication of the document was appropriate, because it was suspected by Indonesian proven fact. Referring to law perspective, in terms of the operations and procedures of arbitration at ICSID, an international arbitration body is in accordance with what is stated in the

34 R-Answers, paragraph 176, cite Golshani v. Government of the Islamic Republic of Iran, IranU.S. Claims Tribunal Case No. 812, Award No. 546-812-3, 2 March 1993, paragraph 49 (Exh. RLA-211); Tr. (Day 1), 26:1-10 (Opening, Frutos-Peterson); Respondent's Opening Statement, Slide 10 on The Award of ICSID on Churchill Mining PLC and Planet Mining Pty Ltd v. Republic of Indonesia.

35 R-PHB1, paragraph 29, n. 55. Tr. (Day 3), 84:2-8 (Cross, Ishak) on The Award of ICSID on Churchill Mining PLC and Planet Mining Pty Ltd v. Republic of Indonesia. convention ICSID itself, while compared to Arbitration in Indonesia mentioned in Article 6 paragraph (1) of Law No. 30 of 1999 with the stated firmly "civil dispute or difference of opinion can be resolved by the parties through alternative dispute resolution that is based on good faith to the exclusion of the litigation settlement in court" which could be said to be more inclined towards the court, but the fact remains resolve the issue between the parties.

Although the Claimants proven falsified documents for a business license, but the ICSID still run arbitration process in accordance with the procedure, as evidenced by processed all file objections and answers from both sides. ICSID was also still considering legal theories proposed by Churchill, although in the end it all turned down. None of the Claimants' theories that continue asserting claims have any merit. These theories are: (i) estoppel, (ii) acquiescence, (iii) fair and equitable treatment ("FET"), including legitimate expectations, (iv) unjust enrichment, and (v) internationally wrongful composite act.

As a general matter, the Claimants' lack of good faith, their awareness of the risks of corruption, their wilful disregard of corruption, and their continued endorsement of Ridlatama's probity precludes them to rely on estoppel, legitimate expectations, acquiescence and other theories. ${ }^{36}$ Taking into account the course of the arbitration proceedings, the evidence and the statement between the two sides, ICSID decided to reject the lawsuit Churchill and ordered

\footnotetext{
36 R-PHB1, paragraph 140 on The Award of ICSID on Churchill Mining PLC and Planet Mining Pty Ltd v. Republic of Indonesia.
} 
Churchill to pay compensation as redress measures against Indonesia.

There were at least 34 documents which contain the signature made by the sophistication of the technology and or performed by non-authorized. The thirty-four is divided into 9 major sections: Survey Licenses; Payment Requests; Cooperation Letters; Legality Letters; Exploration Licenses; Borrowfor-Use Recommendations; Re-Enactment Decrees; Gunter Documents. ${ }^{37}$ Indonesia as the respondent was analyzed that the signatures in documents No. 1-32 were produced "by a piece of very sophisticated technology, most probably an autopen device". Indonesia's expert, Mr. Epstein, confirmed in his reports and at the hearing that Messrs. Ishak, Noor and Setiawan did not sign the disputed documents and that their signatures had been affixed with a so-called "autopen". An autopen uses a master signature that is programed through a smart card or flash drive so as to produce identical signatures in ink. ${ }^{38}$ With different assumptions in this case, however, there is a strong statement that their contents cannot be refuted, because it refers to an element of truth and the absoluteness.

\section{CONCLUSION}

Churchill lawsuit was rejected by the ICSID because it proved to have illegal documents of mining permit in East Kutai, Indonesia. On the plot, Churchill has taken legal action in Indonesia by reporting the case to be processed in Administrative Court Samarinda, Jakarta and an appeal in the Supreme Court of Indonesia, but all over the court ruling stated that Churchill lost in this $37 \quad$ Ibid

38 The Award of ICSID, Op. Cit case. The next step, Churchill sent a letter to President Susilo Bambang Yudhoyono as a complaint for legal protection against them, but to no avail, the grounds, the President viewed the track record of a court decision which has not won Churchill.

In the process of arbitration ICSID own, falsification of documents by Churchill proved by expert analysis forensic handwriting that says that the signature on the document is the result of sophisticated technology weapons called "autopen", in the process of arbitration, ICSID also consider a lot of evidence and statements of two parties for final decision-making process. In this case, Churchill also had tried various things in winning the arbitration by showing evidence that the company's business license of their mines is valid so at the beginning Churchill demanded compensation for the revocation of business licenses to the government of Indonesia, but it was decided that Indonesia won the arbitration and automatically oblige Churchill to pay compensation to the government of Indonesia.

There are number of lessons to be learned from almost five-year dispute between Indonesian government and British mining firm Churchill, which resulted in the Washington based International Centre for Settlement of Investment Disputes (ICSID). The primary lesson is that the central government should strengthen its oversight of the licensing of mining concessions by regional administrations to ensure that mining rights are given to concessions that are clear and clean. The main reason behind the lawsuit by Churchill Mining PLC against the government was the 
questionable permits issued by the regional administration and the forged documents used to support licensing process. And we should magnanimously admit that in most of investment disputes with big investors, especially multinational companies, the Indonesian government, notorious for its poor record of law enforcement and often perceived internationally as one of the most corrupt in the world. The second lesson is that despite Indonesia's victory in the Churchill arbitration case at ICSID Tribunal, which is part of the World Bank, the government should stick to its policy, announced in 2014 , of removing the investor-state disputesettlement (ISDS) mechanism or trade treaties, as many countries have done.

\section{BIBLIOGRAPHY}

Aiste Sklenyte, (2003). International Arbitration: The Doctrine of Separability and Competence-Competence Principle. Aarhus: Winter.

Blackaby Nigel, Constantine Partasides, Alan Redfern, Martin Hunter. (2015). Redfern and Hunter on International Arbitration, 6th Edition. New York: Oxford University Press.

Churchill Mining Plc. Profile. Source: http:// www.churchillmining.com/corporate/ directors/ [Accessed on January 2, 2017]

Convention on the Settlement of Investment Disputes between States and Nationals of Other States 2016.

Diana Loredana Hogaş. (2014). "Principles of law applicable to the arbitration proceedings". Juridical Tribune 4(2): 128-145.
Gatot Supramono. (2012). Hukum Pertambangan Mineral dan Batu Bara di Indonesia, Jakarta: Rineka Cipta.

Huala Adolf. (2002). Arbitrase Komersial Internasional. Jakarta: PT. Rajagrafindo Persada.

Hukum Online. "Pemerintah Digugat Perusahaan Tambang Asing”. http:// www.hukumonline.com/berita/baca/ $\underline{\text { lt4fdb7aa9c6744/pemerintah-digugat- }}$ perusahaan-tambang-asing [Accessed on January 02,2017$]$

Kabir Duggal \& Gerrit Niehoff. (2017). "The Conflicting Landscape Relating to Costs in Investor-State Arbitration", Indian Journal of Arbitration Law, 5(2): 164-176.

Kaczarowska Alina. (2010). Public International Law. London and New York: Routledge.

Law No. 1 of 1967 on Foreign Investment.

Law No. 30 of 1999 on Arbitration and Alternative Dispute Resolution.

Law No. 4 of 2009 on Mineral a Coal Mining. Law No. 5 of 1968 on Dispute Settlement between States and Foreign Citizen regarding to Capital Investment.

M. Yahya Harahap. (2003). Arbitrase, 2nd Edition, Jakarta: Sinar Grafika.

Mateus Aimoré Carreteiro. (2016), “Appellate Arbitral Rules in International Commercial Arbitration". Journal of International Arbitration, 33(2): 185216.

Mohammad Naqib Ishan Jan. (2012). International Dispute Settlement Mechanism, Kuala Lumpur: IIUMPress.

Pojok Satu. "Indonesia Menang Melawan Churchill". Available online from: 
https://goo.g1/FeaCbg [Accessed on Dec 21, 2016]

Rasyid Syed Khalid and Syed Ahmad Idid. (2009). Mediation and Arbitration in Asia Pacific, Malaysia: IIUMPress.

Salim H.S. (2005). Hukum Pertambangan di Indonesia, Jakarta: Rajawali Pers.

Sudikno Mertokusumo. (1999). Mengenal Hukum: Suatu Pengantar, Yogyakarta: Liberty.

Tempo.co. "Indonesia Menang atas Gugatan Arbitrase Churchill Mining”. $\quad$ https://m.tempo.co/read/ news/2016/12/08/058826336/indonesia-menang-atas-gugatan-arbitrase- churchill-mining [Accessed on Jan 2, 2017]

Tempo.co. "Indonesia Wins International Tribunal against Churchill Mining”. Available from https://goo.gl/sOKZzO [Accessed on December 22, 2017] The Award of ICSID on Churchill Mining PLC and Planet Mining Pty Ltd v. Republic of Indonesia.

The Award of ICSID on Churchill Mining PLC and Planet Mining Pty Ltd v. Republic of Indonesia.

Turner Ray, (2005), Arbitration Award: A Practical Approach, Australia: Blackwell Publishing. 